\title{
Enhancing biological nitrogen removal for a retrofit project using wastewater with a low $\mathrm{C} / \mathrm{N}$ ratio-a model-based study
}

\author{
Qian Shao ${ }^{1} \cdot$ Fan Wan $^{2} \cdot$ Weiwei Du ${ }^{3} \cdot$ Jiajie $\mathrm{He}^{1}$ (D) \\ Received: 25 January 2021 / Accepted: 10 May 2021 / Published online: 22 May 2021 \\ (C) The Author(s), under exclusive licence to Springer-Verlag GmbH Germany, part of Springer Nature 2021
}

\begin{abstract}
Anaerobic ammonium oxidation (anammox) has the merit of saving the carbon source and aeration energy for nitrogen $(\mathrm{N})$ removal, but it is normally a challenge to achieve mainstream anammox. In this study, the potential to enhance the N-removal capability of an existing University of Cape Town membrane bioreactor system (UCT-MBR) system is evaluated through process modeling. In addition to external carbon addition, the UCT-MBR system is proposed to be converted into an anoxicoxic (AO) configuration with two operation plans: one is single-sludge (suspended sludge) and the other is double-sludge (suspended sludge and biofilm). The choice between pushing anammox and enhancing conventional heterotrophic denitrification is assessed. The simulation result indicates it is feasible to strategically adjust the spatial-temporal balance between electron donors and electron acceptors to achieve enhanced $\mathrm{N}$-removal by utilizing the influent organic carbon other than adding external carbon. Although anammox can be promoted in the double-sludge-based AO under low-DO conditions, pushing anammox will weaken the system's resilience to influent fluctuations and carries no economic advantage over the single-sludge-based AO. Overall, this study concurs with the United Nations Sustainable Development Goal that the wastewater industry should seek more energy-efficient measures for wastewater treatment.
\end{abstract}

Keywords Aeration $\cdot$ Anammox $\cdot$ Biowin $\cdot$ Modeling $\cdot$ Partial nitrification $\cdot$ Wastewater treatment plant

\section{Introduction}

The United Nations (UN) Sustainable Development Goal (SDG) targets sustainable access to water, sanitation, and hygiene (WASH) services, and highlights less and efficient energy usages (United Nations 2015). The recent outbreak of viral pneumonia (COVID-19) further emphasizes the need for the safe disposal of household wastewater for both urban and rural areas (La Rosa et al. 2020).

The conventional activated sludge (CAS) technology for wastewater treatment presents important economic and technical limitations related to its high-energy requirements. For

Responsible Editor: Ta Yeong Wu

Jiajie He

hejiajie2000@hotmail.com

1 College of Resources and Environment, Huazhong Agricultural University, Wuhan 430070, China

2 Wuhan Planning and Design Co., Ltd., Wuhan 430014, China

3 Sichuan Wentao Engineering and Technologies Co., Ltd., Chengdu 610000, China
CAS-based high-rate biological nutrient removal (BNR) processes, most wastewater treatment plants (WWTPs) generally set dissolved oxygen (DO) to above $2 \mathrm{mg} / \mathrm{L}$ for a stable nitrification performance, although the energy consumption by aeration accounts for nearly half of the total power consumption of WWTPs (Keene et al. 2017). However, external carbon addition is often required to maintain sufficient denitrification of the formed nitrate $\left(\mathrm{NO}_{3}^{-}-\mathrm{N}\right)$. Furthermore, conventional energy-intensive wastewater treatment processes often have the issue of greenhouse gas (GHG) emissions ( $\mathrm{Lu}$ et al. 2018). Nevertheless, with the advancement in the understanding of nitrogen $(\mathrm{N})$ removal mechanisms, it is becoming clear that energy consumption can be reduced for WWTPs through strategic control of the nitrification and denitrification processes.

If nitrification can be maintained at partial nitrification (PN) (Eq. 1) and then starts denitrification from nitrite $\left(\mathrm{NO}_{2}^{-}-\mathrm{N}\right.$ ) (PND) (Eq. 2), it could not only reduce aeration requirements (by $\sim 25 \%$ ) but also save organic carbon consumptions (by $\sim 40 \%$ ) (Peng and Zhu 2006) for the condition with limited biodegradable COD in the wastewater influent. Furthermore, nitrite can be utilized by the anaerobic 
ammonium oxidation (anammox) process to achieve simultaneous nitrite denitrification and ammonium $\left(\mathrm{NH}_{4}^{+}-\mathrm{N}\right)$ oxidation without the need for organic carbon (Eq. 3), which is even more resource conservative than PND (Kartal et al. 2010). The feasibility to couple PN with anammox (PNA) has been proven effective for scenarios of low-C/N wastewater (Jia et al. 2020; Zhang et al. 2020). In addition to PNA, partial denitrification (PdN) (Eq. 4) can also provide nitrite and be coupled with anammox by the name of denitrifying ammonium $o x$ idation (DEAMOX) or PdNA (Du et al. 2019b). Compared to conventional BNR, PdNA can achieve 50\% savings in aeration and $80 \%$ savings in organic carbon consumptions (Du et al. 2019b).

Partial nitrification and denitrification:

$$
\begin{aligned}
& \mathrm{NH}_{4}^{+}+1.37 \mathrm{O}_{2}+0.08 \mathrm{CO}_{2}+0.02 \mathrm{HCO}_{3}^{-} \rightarrow 0.98 \mathrm{NO}_{2}^{-} \\
& \quad+0.02 \mathrm{C}_{5} \mathrm{H}_{7} \mathrm{NO}_{2}+0.97 \mathrm{H}_{2} \mathrm{O}+1.96 \mathrm{H}^{+} \\
& \mathrm{NO}_{2}^{-}+0.67 \mathrm{CH}_{3} \mathrm{OH}+\mathrm{H}^{+} \rightarrow 0.04 \mathrm{C}_{5} \mathrm{H}_{7} \mathrm{O}_{2} \mathrm{~N}+0.48 \mathrm{~N}_{2} \\
& \quad+0.47 \mathrm{CO}_{2}+1.7 \mathrm{H}_{2} \mathrm{O}
\end{aligned}
$$

Anammox:

$$
\begin{gathered}
\mathrm{NH}_{4}^{+}+1.32 \mathrm{NO}_{2}^{-}+0.066 \mathrm{HCO}_{3}^{-}+0.13 \mathrm{H}^{+} \rightarrow 1.02 \mathrm{~N}_{2} \\
+0.26 \mathrm{NO}_{3}^{-}+0.066 \mathrm{CH}_{2} \mathrm{O}_{0.5} \mathrm{~N}_{0.15}+2.03 \mathrm{H}_{2} \mathrm{O}
\end{gathered}
$$

Partial denitrification:

$$
\begin{aligned}
& 1.32 \mathrm{NO}_{3}^{-}+0.55 \mathrm{CH}_{3} \mathrm{COO}^{-}+0.088 \mathrm{NH}_{4}^{+} \rightarrow 1.32 \mathrm{NO}_{2}^{-} \\
& +0.088 \mathrm{C}_{5} \mathrm{H}_{7} \mathrm{NO}_{2}+0.66 \mathrm{HCO}_{3}^{-}+0.198 \mathrm{H}^{+} \\
& +0.264 \mathrm{H}_{2} \mathrm{O}
\end{aligned}
$$

A common requirement for PNA and PdNA is that organic carbon should be minimized to avoid the competition from heterotrophic bacterial (HB) over anaerobic ammoniumoxidizing bacteria (AMX) (Du et al. 2019b). Furthermore, a biomass retention method such as granular sludge, moving bed biofilm reactor (MBBR), and integrated fixed-film activated sludge (IFAS) is required to retain slowly growing AMX from sludge waste (Peng et al. 2019; Pérez et al. 2020; Xie et al.
2020). On the global scale, prevailing wastewater treatment technologies are steadily evolving from conventional energyintensive processes to more energy-efficient or even energyneutral processes (Hao et al. 2019). A lot of efforts have been devoted to the searching for suitable process configurations for mainstream anammox, and it is generally agreed that organic carbon-removal processes should be separated from anammox to avoid the competition between HB and AMX (Jia et al. 2020). One reactor PNA has also been tested by using MBBR to offer a sanctuary for AMX, but the level of organic carbon in the influent should still be pre-reduced to limit the competition from HB (Dimitrova et al. 2020).

In reality, maintaining $\mathrm{PN}$ is delicate due to the difficulty of out-select nitrite-oxidizing bacteria (NOB) (Ali and Okabe 2015), while PdN can be more reliably controlled by limiting the availability of organic carbon (Du et al. 2019a). With increased interests in PdNA, the US EPA recently launched a project to evaluate mainstream PdNA (USEPA 2020), and it is generally agreed that achieving mainstream anammox requires advanced control strategies to provide intensive care of PdN for AMX to thrive (Le et al. 2019).

As for implementing these new N-removal theories, WWTP retrofit projects often lack a "standardized" process configuration in comparison to greenfield designs. Therefore, modelbased investigations are useful for fast and rigorous assessment of retrofit plans, especially in analyzing the interrelations among process units (Jia et al. 2020). The activated sludge model (ASM) family has been developed since the 1980s and has a wide application for WWTPs (van Loosdrecht et al. 2015). However, the conventional ASM series does not carry $\mathrm{PN}, \mathrm{PdN}$, anammox, and GHG emission mechanisms which are of more interests to modern WWTPs. Nevertheless, the framework of ASM is open for modifications and extensions, and there are successful commercial modeling platforms to suit the industrial needs by including more complex processes and considering more factors (Dorofeev et al. 2017; Elawwad 2018; Díez-Montero et al. 2019).

In this study, a model-based approach is applied to evaluate the feasibility of a WWTP retrofit project brought to the authors recently. A University of Cape Town (UCT) process upgraded from the cyclic activated sludge system (CASS) was found insufficient to meet the discharge limit due to lack of denitrification. As a response, three modification plans are proposed: (1) implement real-time effluent nitrate-based feedback control of extra carbon addition to enhance heterotrophic denitrification; (2) convert the UCT to a moderately aerated single-sludge (suspended sludge) anoxic-oxic ( $\mathrm{AO}$ ) process to prevent excessive anoxic consumptions of influent organic carbon; and (3) convert the UCT to a moderately aerated double-sludge (suspended sludge and biofilm) AO process to further promote anammox. For the two AO plans, multiple influent feeding is used to better exploit the influent organic 
carbon for denitrification. Model-based evaluations are conducted for both static and dynamic conditions. The ultimate purpose of this study is to concur with the UN SDG that the wastewater industry should and can seek more energyefficient measures for wastewater treatment.

\section{Materials and methods}

\section{Model setup}

A CASS process was upgraded to UCT, and its aerobic volume was increased by adding an aerobic membrane reactor (MBR) to replace the function of the secondary sedimentation tank. The resulting hydraulic retention time (HRT) was $12.5 \mathrm{~h}$ for an average flow of 22,500 $\mathrm{m}^{3} /$ day (Fig. S1). However, a year-long operation of this UCT-MBR system indicated poor biological P and $\mathrm{N}$ removals, and external carbon addition is required to enhance system denitrification capability. In addition to the option of external carbon addition, two other modification plans are also proposed to enhance system N-removal without the need to significantly change the physical structure of the process train.

One plan is to convert the UCT-MBR system into an AO process with the MBR basin to be the oxic zone (O-zone) (hereafter referred to as single-sludge-based AO plan). Aeration to the O-zone is proposed to be tuned down to promote the system potential of PNA along with multiple influent feeding to better exploit the carbon source in the influent for denitrification in the anoxic zone (A-zone). Another proposed plan is the same as the first one, but MBBR biofilm carriers are added into the A-zone to make it a double-sludge system to further enhance the chance to promote anammox (hereafter referred to as double-sludge-based AO plan). Both AO plans have "swing" zones in the A-zone to offer the flexibility to adjust the aerobic and anoxic volumes of the system.

The proposed modification plans are implemented in BioWin Process Simulator v6.0 (EnviroSim Associates Ltd., Ontario, Canada) (Fig. 1). The BioWin general model (ASDM) is adopted, which includes PN, PdN, and anammox. The mechanisms of PN and anammox are well established from the modeling perspective ( $\mathrm{Ni}$ et al. 2015), but the PdN theory is still in progress regarding the responsible microorganisms and carbon sources (Cao et al. 2013, 2016; Du et al. 2019a). In ASDM, PdN is set to occur simultaneously with full denitrification at a rate $50 \%$ less of the full denitrification. The 1-year influent (COD averaged at $170 \mathrm{mg} / \mathrm{L}, \mathrm{TN}$ averaged at $23.41 \mathrm{mg} / \mathrm{L}, \mathrm{NH}_{4}^{+}-\mathrm{N}$ averaged at $15.05 \mathrm{mg} / \mathrm{L}$ ) and effluent record (Fig. S2) of the UCT-MBR is used as the model input. The influent COD fractions were analyzed per the method of Melcer et al. (2003) (Table 1). The stoichiometric and kinetic parameters used the default values of ASDM.
The characteristics of the influent wastewater of this study (low biodegradable $\mathrm{COD}$ and $\mathrm{C} / \mathrm{N}$ ratio) are not suitable for biological $\mathrm{P}$ removal, and chemical precipitation and efficient effluent filtration will be a more reliable engineering practice for P removal for such type of wastewater (ASCE 2010). Therefore, $\mathrm{P}$ removal is not discussed in this study. Furthermore, the high ratio of un-biodegradable COD indicates the possibility of unregulated industrial discharge into the sewer system, which is often encountered in developing countries including China.

$2 \%$ is assumed to be active biomass

\section{Evaluation criteria}

The effects of the operating conditions (DO, sludge retention time (SRT), and water temperature) on system performance are evaluated first in terms of effluent $\mathrm{N}$ (total nitrogen (TN), $\mathrm{NH}_{4}^{+}-\mathrm{N}, \mathrm{NO}_{2}^{-}-\mathrm{N}, \mathrm{NO}_{3}^{-}-\mathrm{N}$ ) levels and biodegradable $\mathrm{COD}$ distributions through steady-state simulations using the commonly used $200 \mathrm{mg} / \mathrm{L}$ of total COD, $30 \mathrm{mg} / \mathrm{L}$ of TKN. Then, a plant-wide evaluation in terms of effluent quality and operational costs is carried using the 1-year influent record as the input.

The evaluation criteria used for dynamic conditions are the effluent quality index (EQI) and the operational cost index (OCI) defined in the Benchmark Simulation Model No. 2 (BSM2) (Gernaey et al. 2014). The EQI is calculated as a weighted sum of the effluent concentrations of COD, TKN, nitrate and nitrite nitrogen $(\mathrm{NO})$, and $\mathrm{BOD}_{5}$, averaged over 1 year (Eq. 5).

$$
\begin{aligned}
\mathrm{EQI}= & \frac{1}{t_{\mathrm{obs}} \cdot 1000} \int_{t_{\text {satat }}}^{t_{\text {end }}} \\
& \left(+\beta_{\mathrm{COD}} \cdot \operatorname{COD}(t)+\beta_{\mathrm{TN}} \cdot S_{T N}(t)+\beta_{\mathrm{NO}} \cdot S_{N O}(t)+\beta_{\mathrm{BOD}_{5}} \cdot B O D_{5}(t)\right) \cdot \mathrm{Q}(t) \cdot d t
\end{aligned}
$$

where $\beta_{\mathrm{COD}}=1, \beta_{\mathrm{TN}}=30, \beta_{\mathrm{NO}}=10, \beta_{\mathrm{BOD}_{5}}=2$.

The OCI is calculated as a weighted sum of aeration energy (AE, $\mathrm{kWh} /$ day), pumping energy ( $\mathrm{PE}, \mathrm{kWh} /$ day), mixing energy (ME, kWh/day), sludge production for disposal (SP, kg $\mathrm{SS} /$ day), external carbon addition (EC, $\mathrm{kg} \mathrm{COD/d}$ ) (Eq. 6). Since no digester is utilized in this study, the credits from methane production and the cost of digester heating energy

Table 1 Influent COD fractions (\%)

\begin{tabular}{lll}
\hline & Average & Range \\
\hline Fbs, soluble biodegradable & 0.2314 & $(0.04 \sim 0.42)$ \\
Fus, soluble nonbiodegradable & 0.2680 & $(0.23 \sim 0.30)$ \\
Fup, particulate nonbiodegradable & 0.1611 & $(0.10 \sim 0.24)$ \\
Fxs, slowly biodegradable & 0.3195 & $(0.20 \sim 0.47)$ \\
\hline
\end{tabular}




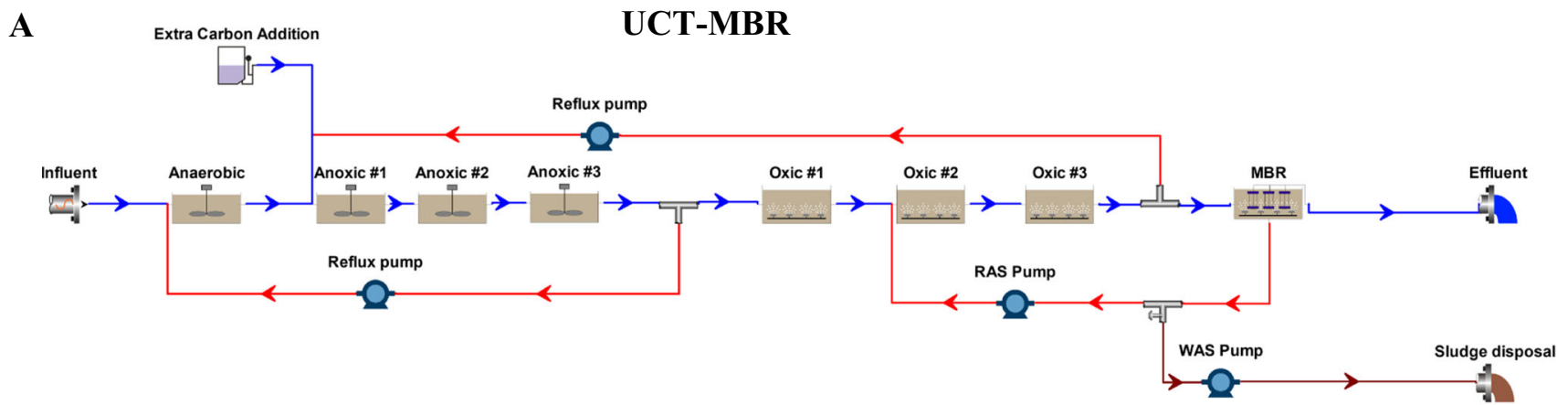

B

Single-sludge based AO

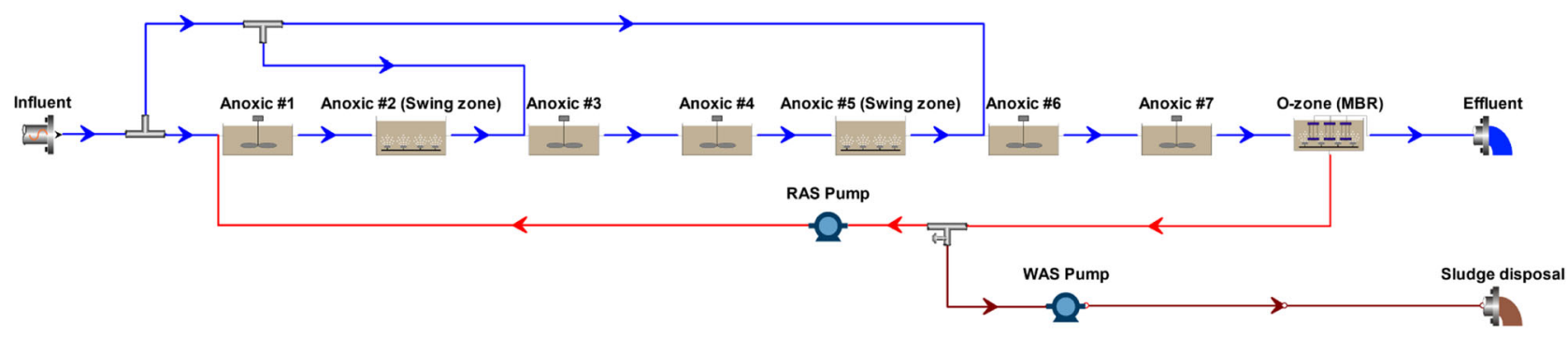

C

Double-sludge based AO

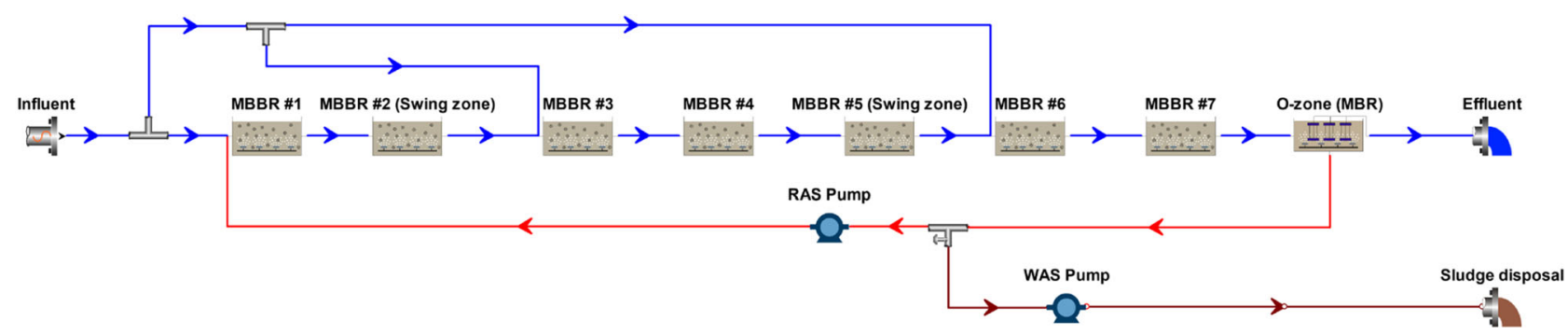

Fig. 1 The proposed modification plans. (1. Influent is evenly distributed among the three feeding points of the two AO plans; 2. 10\% of the MBBR tank is set to be filled with media, and the media-specific area is set to $125 \mathrm{~m}^{2} / \mathrm{m}^{3}$ )

are not considered.

$\mathrm{OCI}=A E+P E+M E+f_{S P} \cdot S P+f_{E C} \cdot E C$

where $f_{S P}=3, f_{E C}=3$.

\section{Results and discussion}

\section{System performance under static conditions}

The feasibility to promote denitrification is evaluated through static simulations. The simulated fate of biodegradable COD (hereafter referred to as bCOD) under varying DO, SRT, and temperature levels are comparably illustrated in Fig. 2 and 3 for the two proposed AO plans. It is demonstrated that the distributions of applied bCOD among sludge growth, effluent discharge, and mineralization (both anoxic and aerobic) do not demonstrate remarkable differences over the change of DO,
SRT, and temperature. This is because the testing SRT and HRT levels are sufficient to offer adequate removal of the applied bCOD, and the biomass yield coefficients of bCOD also do not change by the operating parameters as defined by the model framework.

However, lowering the DO setpoint can lead to increased anoxic consumption of bCOD, which is a favorable sign for heterotrophic denitrification. Such impact of adjusting the DO in the A-zone is more pronounced than adjusting the DO in the "swing" zones of the O-zone. This is because most of the anoxic removals of bCOD occur in the A-zone and the role of the O-zone is to polish unremoved bCOD and $\mathrm{NH}_{4}^{+}-\mathrm{N}$ left from the A-zone. Furthermore, the double-sludge-based AO plan has a higher extent of anoxic process activities versus the oxic process activities than that of the single-sludge based AO plan, which is ascribed to the increased biomass from the MBBR biofilm carriers.

The benefit of directing more bCOD to anoxic processes by reducing the DO setpoints is the reduced effluent $\mathrm{TN}$ and $\mathrm{NO}_{3}^{-}$ 

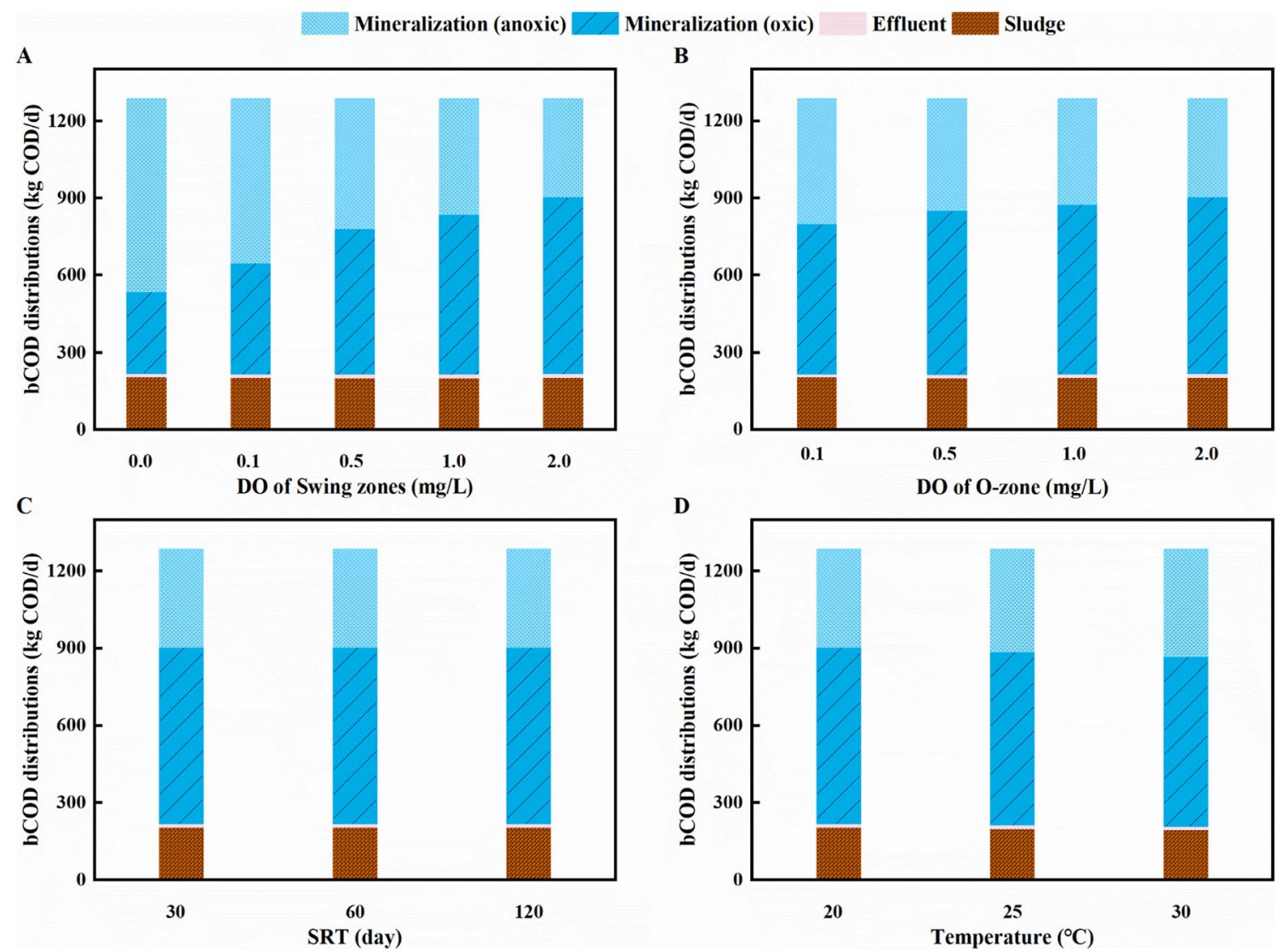

Fig. 2 bCOD distributions under varying system operation parameters of the single-sludge-based AO. (The base scenario is SRT $=120$ days to maintain a high biomass concentration in the system, temperature $=25^{\circ} \mathrm{C}, \mathrm{DO}=2.0 \mathrm{mg} / \mathrm{L}$ for both the "swing" zones and the O-zone)

-N levels (Fig. 4 and 5). However, adjusting the DO in the Ozone has a more pronounced effect on the effluent TN and $\mathrm{NO}_{3}^{-}-\mathrm{N}$ levels than adjusting the $\mathrm{DO}$ in the "swing" zones. Although temperature has no remarkable impact on the bCOD's fate, increase temperature can noticeably improve N-related biological activities and lead to higher TN removals. These indicate the system's N-removal capacity does not have too much redundancy regarding the $\mathrm{N}$-removal requirement over the influent, but the system's bCOD removal capacity is significantly larger than required, which can be strategically adjusted to favor the N-removal requirement. While the effluent under all DO setting combinations can meet the commonly used wastewater discharge limit on $\mathrm{TN}(<15 \mathrm{mg} / \mathrm{L})$ and $\mathrm{NH}_{4}^{+}$ $-\mathrm{N}(<5.0 \mathrm{mg} / \mathrm{L})$, the simulated effluent $\mathrm{N}$ profiles are still higher than the limit of $\mathrm{TN}<5.0 \mathrm{mg} / \mathrm{L}$ which is gradually implemented in China. Furthermore, lowering the DO in the O-zone to $0.1 \mathrm{mg} / \mathrm{L}$ demonstrates the possibility of promoting $\mathrm{PN}$ for both AO plans which is crucial for anammox.

The simulated $\mathrm{bCOD}$ and $\mathrm{N}$ profiles, and microbial activities over the process train of the unmodified UCT-MBR system and the two AO plans (for two conservative DO setting combinations: $\mathrm{DO}=0 \mathrm{mg} / \mathrm{L}$ for the "swing" zones, $\mathrm{DO}=0.1$ $\mathrm{mg} / \mathrm{L}$ and $0.5 \mathrm{mg} / \mathrm{L}$ for the O-zone, respectively) are comparably illustrated in Fig. 6. From a general perspective, in both two AO plans, the O-zone is mainly responsible for polishing the bCOD and $\mathrm{NH}_{4}^{+}-\mathrm{N}$ left from the A-zone, and the A-zone is responsible for the removal of the influent bCOD and $\mathrm{NO}_{3}^{-}$ $-\mathrm{N}$ circulated back from the O-zone. For both AO plans, setting the DO in the O-zone to $0.5 \mathrm{mg} / \mathrm{L}$ (hereafter referred to as $0.5 \mathrm{mg} / \mathrm{L}$ DO scenario) will lead to slightly increased oxic processes in the front of the A-zone. On the contrary, setting the DO in the O-zone to $0.1 \mathrm{mg} / \mathrm{L}$ (hereafter referred to as $0.1 \mathrm{mg} / \mathrm{L}$ DO scenario) will promote $\mathrm{PN}$ in the O-zone and the formed $\mathrm{NO}_{2}^{-}-\mathrm{N}$ is circulated back to the front of the A-zone to facilitate anammox.

The bCOD availability is found crucial to maintain denitrification in the A-zone. The reason for the unmodified UCT to have higher effluent $\mathrm{TN}$ and $\mathrm{NO}_{3}^{-}-\mathrm{N}$ levels is that most of its influent bCOD are lost to aerobic consumptions so $\mathrm{NO}_{3}^{-}-\mathrm{N}$ cannot be adequately denitrified (Fig. 6F, K). On the other hand, the multiple influent feeding strategy can avoid excessive bCOD lost to aerobic consumption in the front of the Azone. It is also demonstrated that under the $0.5 \mathrm{mg} / \mathrm{L} \mathrm{DO}$ scenario, each influent feeding can boost the overall biological activities in the receiving basins (Fig. 6N, O), but under the $0.1 \mathrm{mg} / \mathrm{L}$ DO scenario, the boosting effect from each influent feeding (Fig. 6L, M) is noticeably weaker than that of the 0.5 $\mathrm{mg} / \mathrm{L}$ DO scenario. These indicate that a higher DO setting 

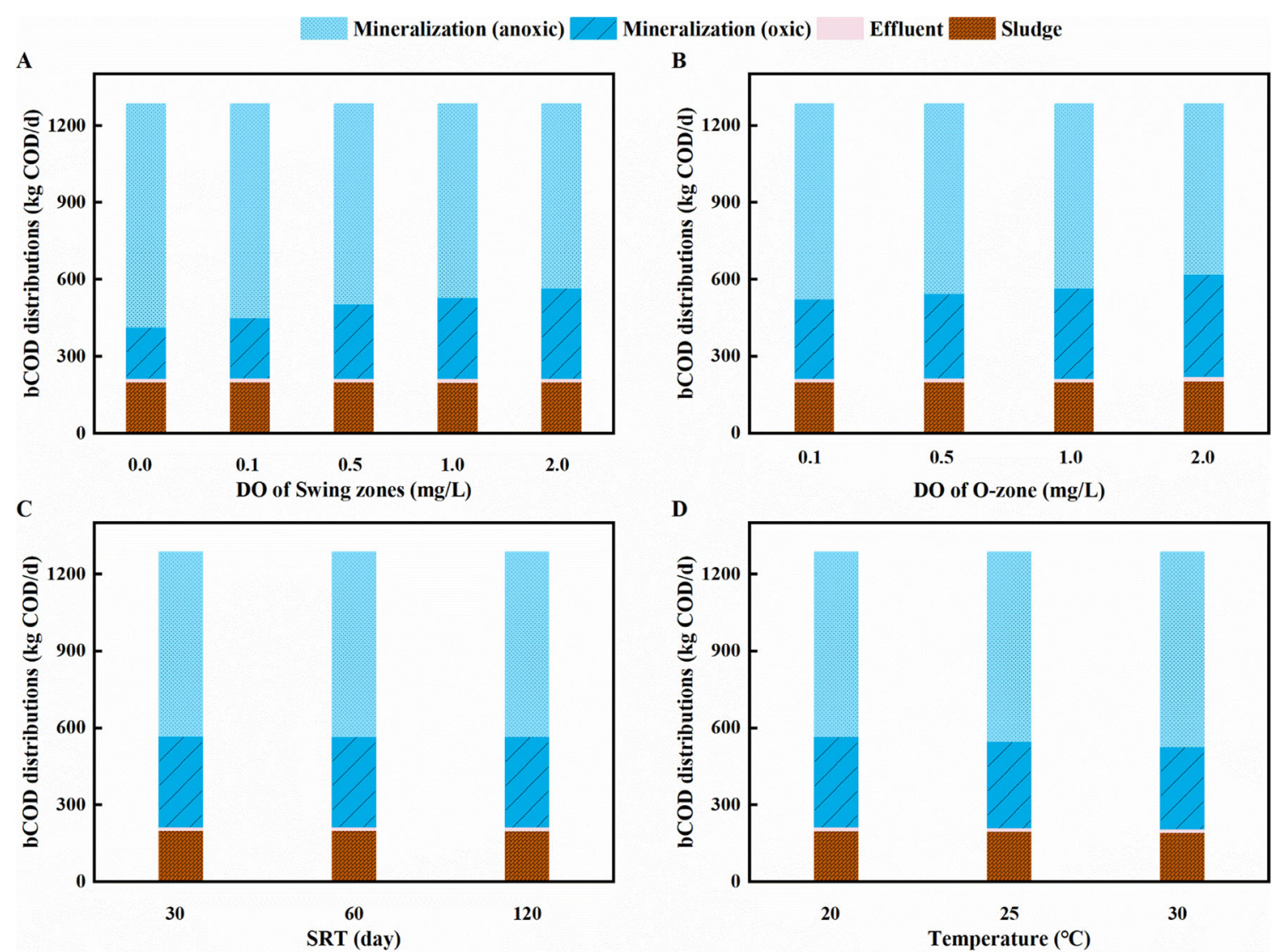

Fig. 3 bCOD distributions under varying system operation parameters of the double-sludge-based AO. (The base scenario is SRT $=120$ days to maintain a high biomass concentration in the system, temperature $=25^{\circ} \mathrm{C}, \mathrm{DO}=2.0 \mathrm{mg} / \mathrm{L}$ for both the "swing" zones and the O-zone)

demands a higher electron donor (e.g., organic carbon, $\mathrm{NH}_{4}^{+}$ $-\mathrm{N}$ ) supply to match it, so for a low organic carbon wastewater the supply of oxygen should be regulated to prevent access aerobic consumption of the limited organic carbon in the influent.

Regarding anammox, AMX activities are noticeably promoted in the double-sludge-based AO plan, but only negligible levels of AMX activities are demonstrated in the singlesludge-based AO plan (Fig. 6 L-O). For the double-sludgebased AO plan, although the biofilm is dominated by anoxic processes (including both heterotrophic denitrification and anammox), denitrification is still largely carried by the HB in the suspended sludge (Fig. $6 \mathrm{M}, \mathrm{O}$ ). These simulation results are in agreement with experimental observations that AMX is more distributed in granular sludge or biofilms than in suspended sludge since AMX requires biomass retention to prevent washout (Laureni et al. 2016).

Even so, the AMX activities are higher under the $0.1 \mathrm{mg} / \mathrm{L}$ DO scenario than under the $0.5 \mathrm{mg} / \mathrm{L}$ DO scenario. This outcome indicates $\mathrm{NO}_{2}^{-}-\mathrm{N}$ produced by $\mathrm{PdN}$ in the A-zone under the $0.5 \mathrm{mg} / \mathrm{L}$ DO scenario is not sufficient to promote a comparable extent of anammox with that of the $0.1 \mathrm{mg} / \mathrm{L} \mathrm{DO}$ scenario, under which $\mathrm{NO}_{2}^{-}-\mathrm{N}$ produced in the O-zone is made readily available for AMX after being circulated to the A-zone. This is because under the $0.5 \mathrm{mg} / \mathrm{L}$ DO scenario, the bCOD is sufficient to allow HB to compete with AMX by denitrifying both $\mathrm{NO}_{3}^{-}-\mathrm{N}$ and $\mathrm{NO}_{2}^{-}-\mathrm{N}$ generated by $\mathrm{PdN}$, while under the $0.1 \mathrm{mg} / \mathrm{L}$ DO scenario $\mathrm{NO}_{2}^{-}-\mathrm{N}$ generated in the MBR basin is readily available for AMX after being circulated back to the front of the process.

As for the microbial composition in the biofilm of the double-sludge-based AO, it is shown that AMX flourishes in the outer layer of the biofilm while HB dominates the entire biofilm (Fig. 7). For the solely biofilm-based anammox process, AMX often resides in the inner layer of biofilms due to substrate diffusion that influences the electron competition among microorganisms (Dimitrova et al. 2020; Li et al. 2020; Pan et al. 2019). But for double-sludge systems that segregate biomass between granules/biofilm and flocs, AMX normally flourishes in the outer layer of biofilms since the required $\mathrm{NO}_{2}^{-}-\mathrm{N}$ can be readily provided by the nitrifiers in the flocculated sludge and the competition pressure from HB can also be shared by the flocculated sludge (Seuntjens et al. 2020; Zhu et al. 2018), which is the case of this study.

It is also shown that under the $0.1 \mathrm{mg} / \mathrm{L}$ DO scenario, the AMX activities decrease over the process train, which is due to 


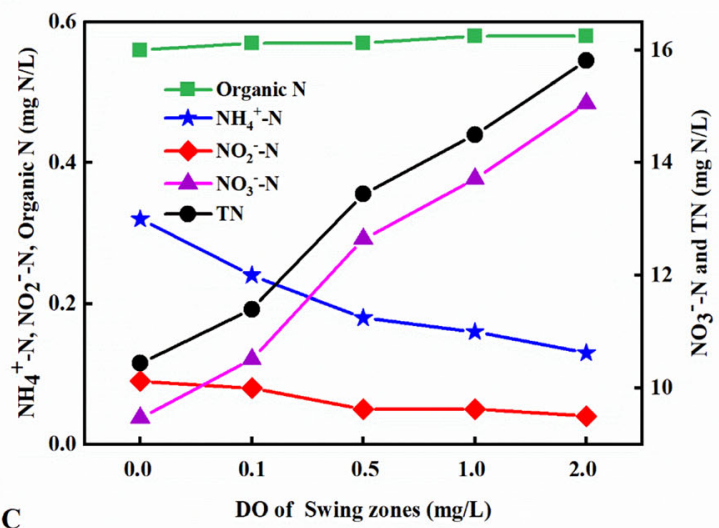

C

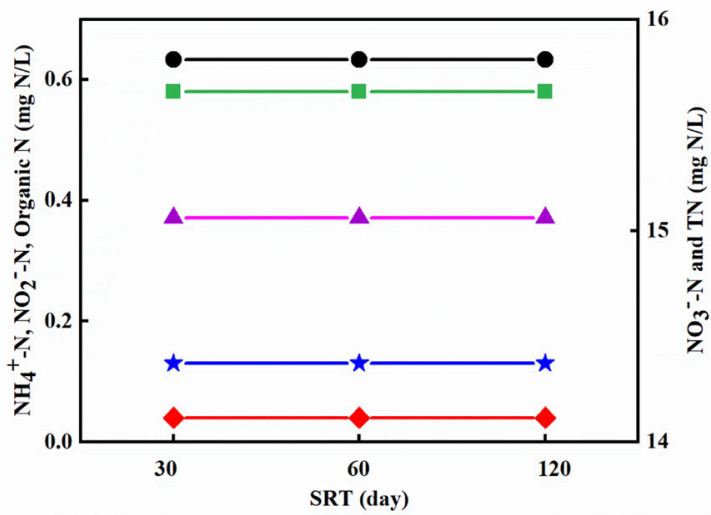

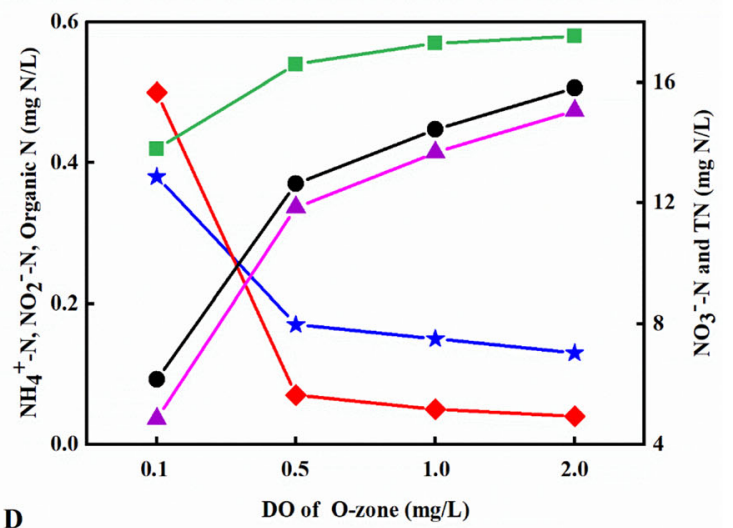

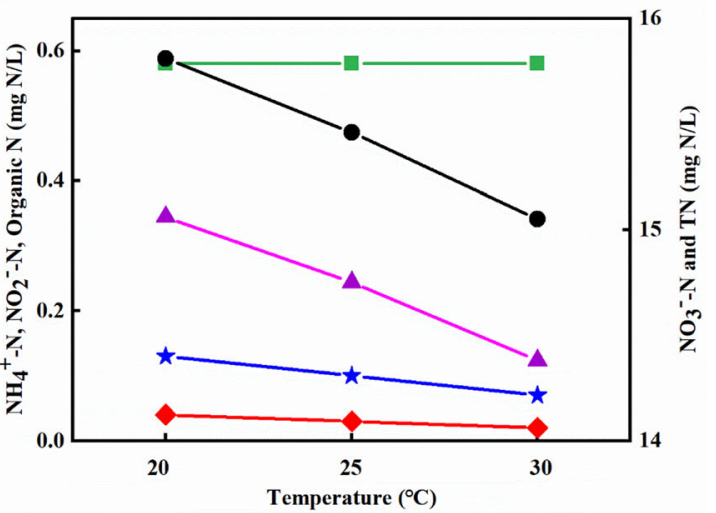

Fig. 4 The effluent $\mathrm{N}$ profiles under varying system operation parameters of the single-sludge-based AO. (The base scenario is SRT = 120 days, temperature $=25^{\circ} \mathrm{C}, \mathrm{DO}=2.0 \mathrm{mg} / \mathrm{L}$ for both the swing-zone and the O-zone)

the consistently reduced level of $\mathrm{NO}_{2}^{-}-\mathrm{N}$ (Fig. 6C). However, under the $0.5 \mathrm{mg} / \mathrm{L}$ DO scenario, the AMX activities increase over the process train before each influent feeding, and each influent feeding noticeably reduces the AMX activities. This is because in the model framework, $\mathrm{NO}_{2}^{-}-\mathrm{N}$ can only be conserved for anammox if organic carbon is not enough for further denitrification of $\mathrm{NO}_{2}^{-}-\mathrm{N}$, and the simulation outcome conforms to experimental observations that $\mathrm{PdN}$ requires delicate controls of organic carbon addition (Cao et al. 2013; Du et al. 2019b; Le et al. 2019). The contrast between the 0.1 and 0.5 $\mathrm{mg} / \mathrm{L} \mathrm{DO}$ scenarios also demonstrates that $\mathrm{NO}_{2}^{-}-\mathrm{N}$ availability (pre-ready versus immediate generation among competitive environment) has a pronounced impact on AMX activities (Le et al. 2019; Jia et al. 2020).

Furthermore, the microorganism activities (Fig. 6 L, M, N, O) and biofilm growths (Fig. 7) are lower under the $0.1 \mathrm{mg} / \mathrm{L}$ DO scenario, especially for those downstream units of the Azone. This outcome indicates the biological potentials in those downstream basins are far from being fully exploited under the $0.1 \mathrm{mg} / \mathrm{L}$ DO scenario, and thus can be conserved as effective swing zones to respond to influent fluctuations. However, how to utilize these swing zones deserves further studies depending on the research goals, which are not explored in this study.
Regarding $\mathrm{N}_{2} \mathrm{O}$ emissions, it is demonstrated that the overall $\mathrm{N}_{2} \mathrm{O}$ generations under the $0.1 \mathrm{mg} / \mathrm{L}$ DO scenarios are one magnitude higher than that of the $0.5 \mathrm{mg} / \mathrm{L} \mathrm{DO}$ scenarios, and the unmodified UCT-MBR system has the lowest $\mathrm{N}_{2} \mathrm{O}$ generations (Fig. 8). Regarding the location of major $\mathrm{N}_{2} \mathrm{O}$ generations, most $\mathrm{N}_{2} \mathrm{O}$ generations occur in the aerobic units of the process train, but a low DO setpoint has a higher $\mathrm{N}_{2} \mathrm{O}$ generation, which conforms to the theoretical DO impact on $\mathrm{N}_{2} \mathrm{O}$ generations (Ni et al. 2013). This simulation result also conforms to the reality that $\mathrm{N}_{2} \mathrm{O}$ emission from WWTP is normally associated with AOB activities, either as a by-product of incomplete nitritation or as a result of denitrification carried by AOB under low-DO conditions (Ni et al. 2013, 2015). Nevertheless, it is indicated that pushing anammox might not be the only option since optimizing WWTP operation should consider more than just effluent $\mathrm{N}$ profiles which will be illustrated by the following section of dynamic evaluation.

\section{System performance under dynamic conditions}

The simulated 1-year effluent $\mathrm{NH}_{4}^{+}-\mathrm{N}$ and $\mathrm{NO}_{3}^{-}-\mathrm{N}$ profiles of the two AO plans (both $0.1 \mathrm{mg} / \mathrm{L}$ and $0.5 \mathrm{mg} / \mathrm{L} \mathrm{DO}$ scenarios) are comparably illustrated in Fig. 9 against the scenarios of UCT-MBR with and without external carbon additions. It is 
A

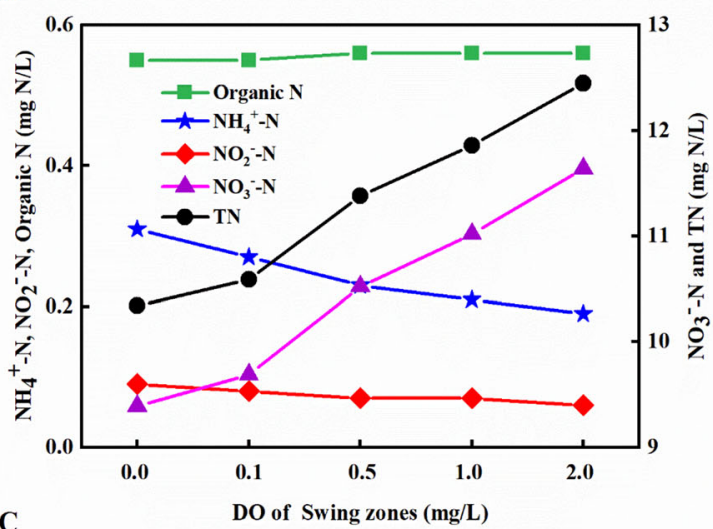

C

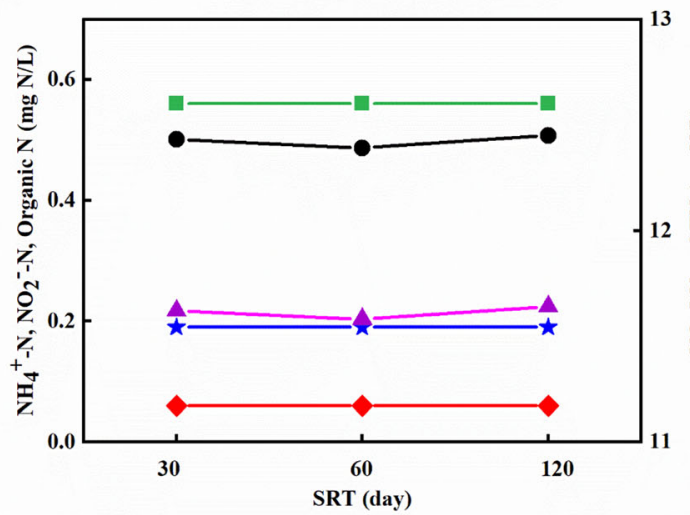

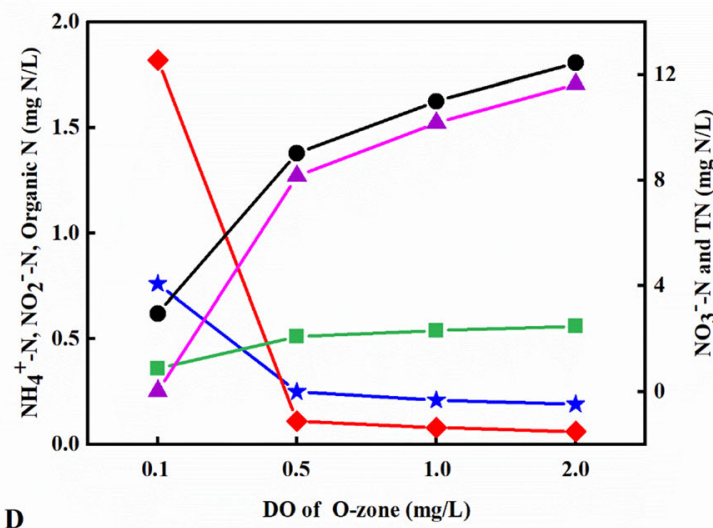

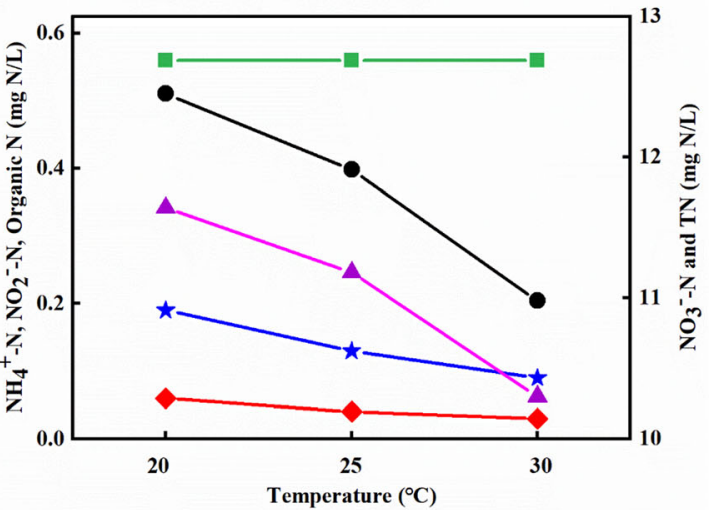

Fig. 5 The effluent $\mathrm{N}$ profiles under varying system operation parameters of the double-sludge-based AO. (The base scenario is SRT $=120$ days, temperature $=25^{\circ} \mathrm{C}, \mathrm{DO}=2.0 \mathrm{mg} / \mathrm{L}$ for both the swing-zone and the O-zone)

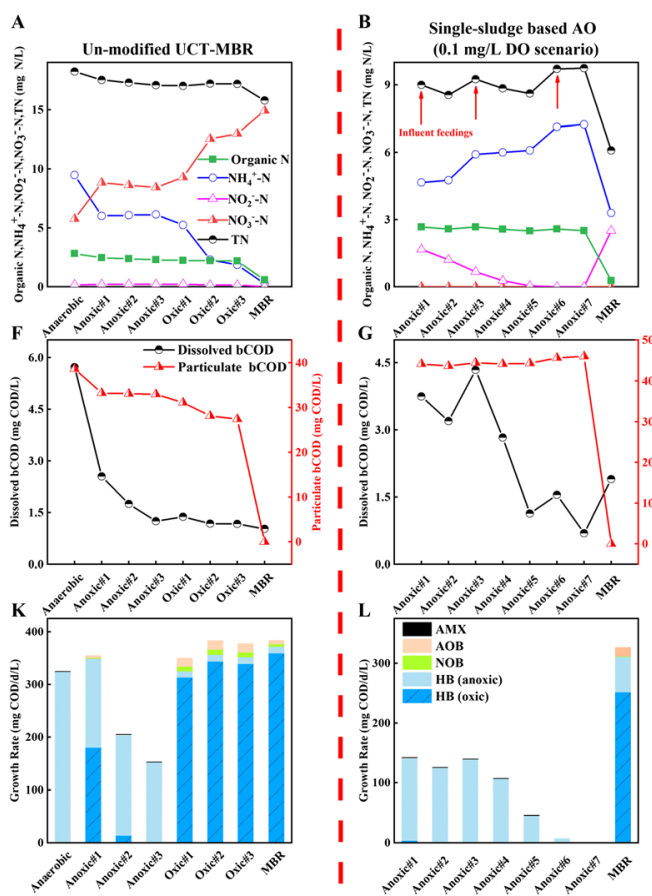

Fig. 6 The bCOD, N, and microbial profiles over the process train of the two AO plans and the unmodified UCT-MBR. (AMX, anaerobic ammonium-oxidizing bacteria; AOB, ammonium-oxidizing bacteria;
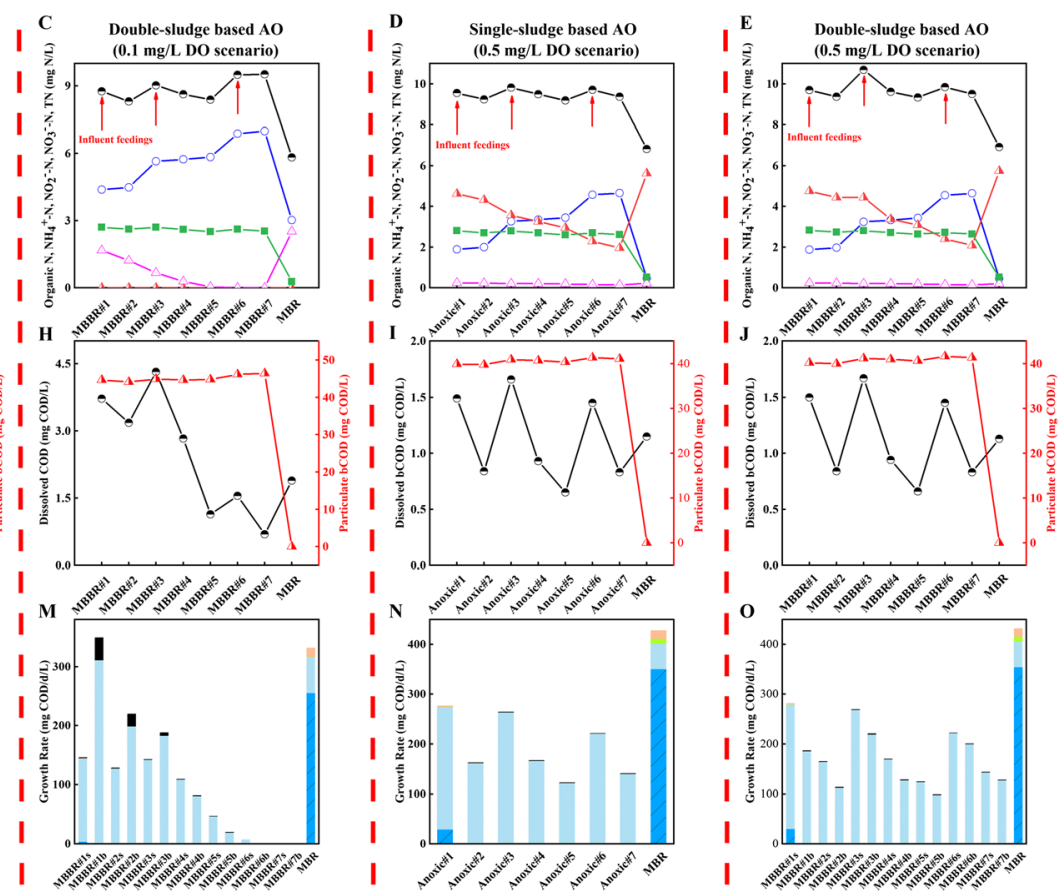

$\mathrm{NOB}$, nitrite-oxidizing bacteria; $\mathrm{HB}$, heterotrophic bacteria; for $\mathrm{M}$ and $\mathrm{O}$, s stands for suspended sludge, $\mathrm{b}$ stands for biofilm) 
$\square \mathrm{HB} \square \mathrm{AMX}$
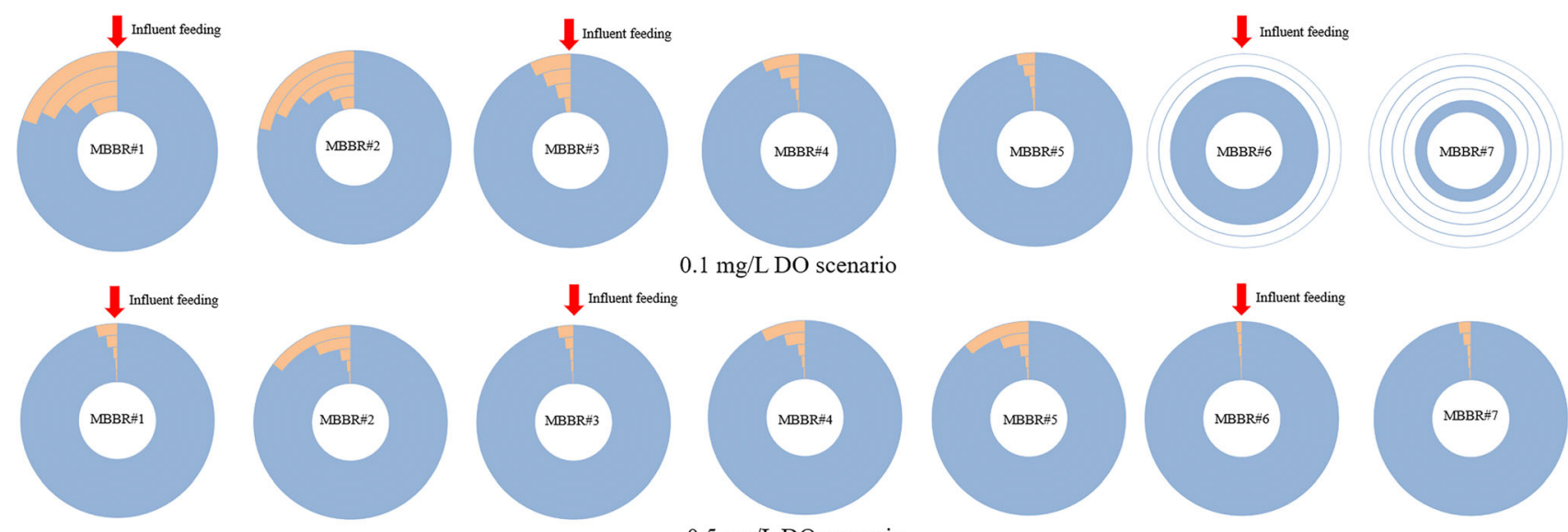

$0.1 \mathrm{mg} / \mathrm{L} \mathrm{DO}$ scenario
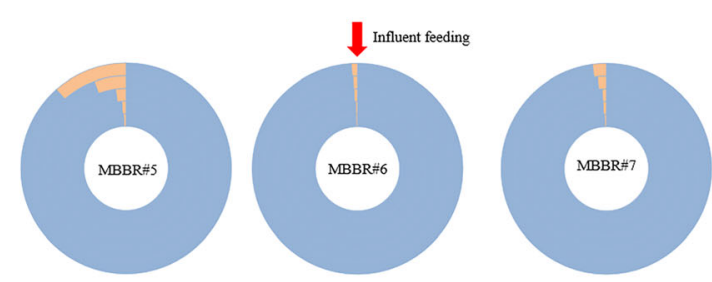

$0.5 \mathrm{mg} / \mathrm{L}$ DO scenario

Fig. 7 Microbial activities in the MBBR biofilm over the double-sludge based AO process train. (1. AMX, anaerobic ammonium-oxidizing bacteria; $\mathrm{HB}$, heterotrophic bacteria; 2 . nitrifying bacteria are omitted due to their negligible activities on biofilms; 3 . the total biofilm depth is set to $500 \mu \mathrm{m}$ and is divided into 5 layers for simulation) demonstrated that temperature has a pronounced effect on effluent $\mathrm{N}$ levels, with a higher temperature leading to higher effluent $\mathrm{NO}_{3}^{-}-\mathrm{N}$ levels. However, under the $0.1 \mathrm{mg} / \mathrm{L}$ DO scenarios, both AO plans cannot deliver a consistent effluent $\mathrm{NH}_{4}^{+}-\mathrm{N}$ to meet the regularly adopted discharging limit of $1.0 \mathrm{mg} \mathrm{NH}_{4}^{+}-\mathrm{N} / \mathrm{L}$. This is because the $0.1 \mathrm{mg} / \mathrm{L}$ DO setpoint cannot deliver a system nitrification capacity to adequately nitrify the influent $\mathrm{NH}_{4}^{+}-\mathrm{N}$ during low-temperature seasons. Although the biological potential of those downstream Azone units of the $0.1 \mathrm{mg} / \mathrm{L} \mathrm{DO}$ scenarios has not been fully enhanced, changing the balance between electron donors and acceptors for those basins might break the delicately established anammox system under the $0.1 \mathrm{mg} / \mathrm{L}$ DO scenario.

Meanwhile, with the help of real-time control of the external carbon addition and sufficient aeration, the UCT-MBR system can deliver consistent effluent $\mathrm{N}$ profiles comparable to the two AO plans disregarding influent fluctuations. Therefore, although lowering the DO setpoint can achieve a comparable N-removal result to external carbon addition, the simulation results indicate lowering DO in the AO configuration to push anammox might risk losing the system's resilience to influent fluctuations, and also implicates the merit of using the A-B process to buffer the impact of influent fluctuations on N removals (Jia et al. 2020).

In terms of the system performance and operations under the $0.5 \mathrm{mg} / \mathrm{L}$ DO scenario, it is demonstrated that the double-sludgebased AO plan cannot deliver a better effluent EQI than the single-sludge-based AO plan (Fig. 10A). Furthermore, although the two AO plans have OCI values noticeably lower than the UCT-MBR systems (Fig. 10B), the double-sludge-based AO plan has a slightly higher OCI value than the single-sludgebased $\mathrm{AO}$ plan due to the extra mixing power requirement incurred by MBBR biofilm carriers (Fig. 10B). It is also worthwhile to mention that the $\mathrm{AO}$ configuration in this study is adopted to direct the influent carbon source more toward denitrification, rather than to be captured for carbon recovery as in the A-B process (Jia et al. 2020). Overall, as demonstrated in this study, it is not necessary to push anammox for N-removal if conservative aeration and multiple influent feeding strategy can already achieve comparable results. Nevertheless, this claim is inconclusive and only applicable to this particular study since WWTP retrofit/upgrade projects often face various technical options and limitations. For what is more, it is suggested that GHG emissions should be included in the EQI and/or OCI to better address the requirement of the UN SDG campaign.
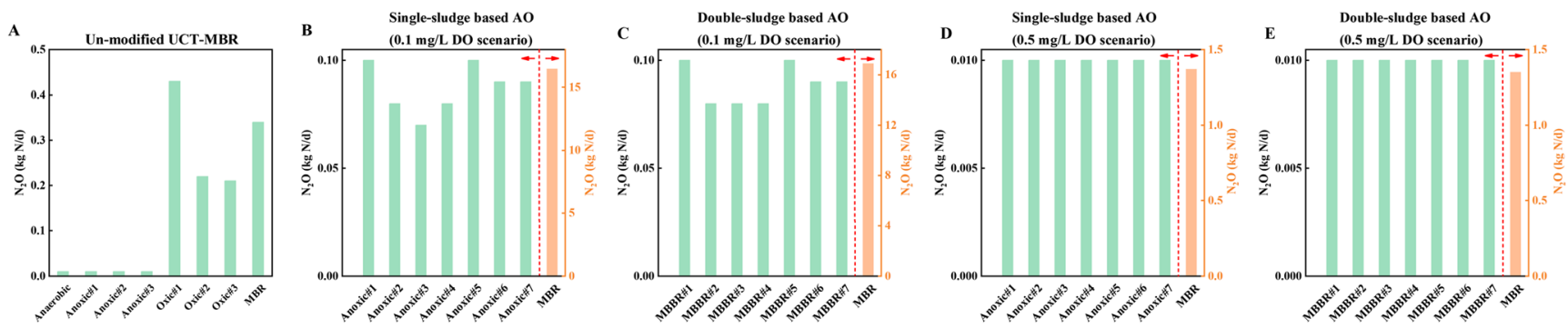

Fig. $8 \mathrm{~N}_{2} \mathrm{O}$ emissions over the process train of the unmodified UCT system and the two AO plans under two DO setting scenarios 

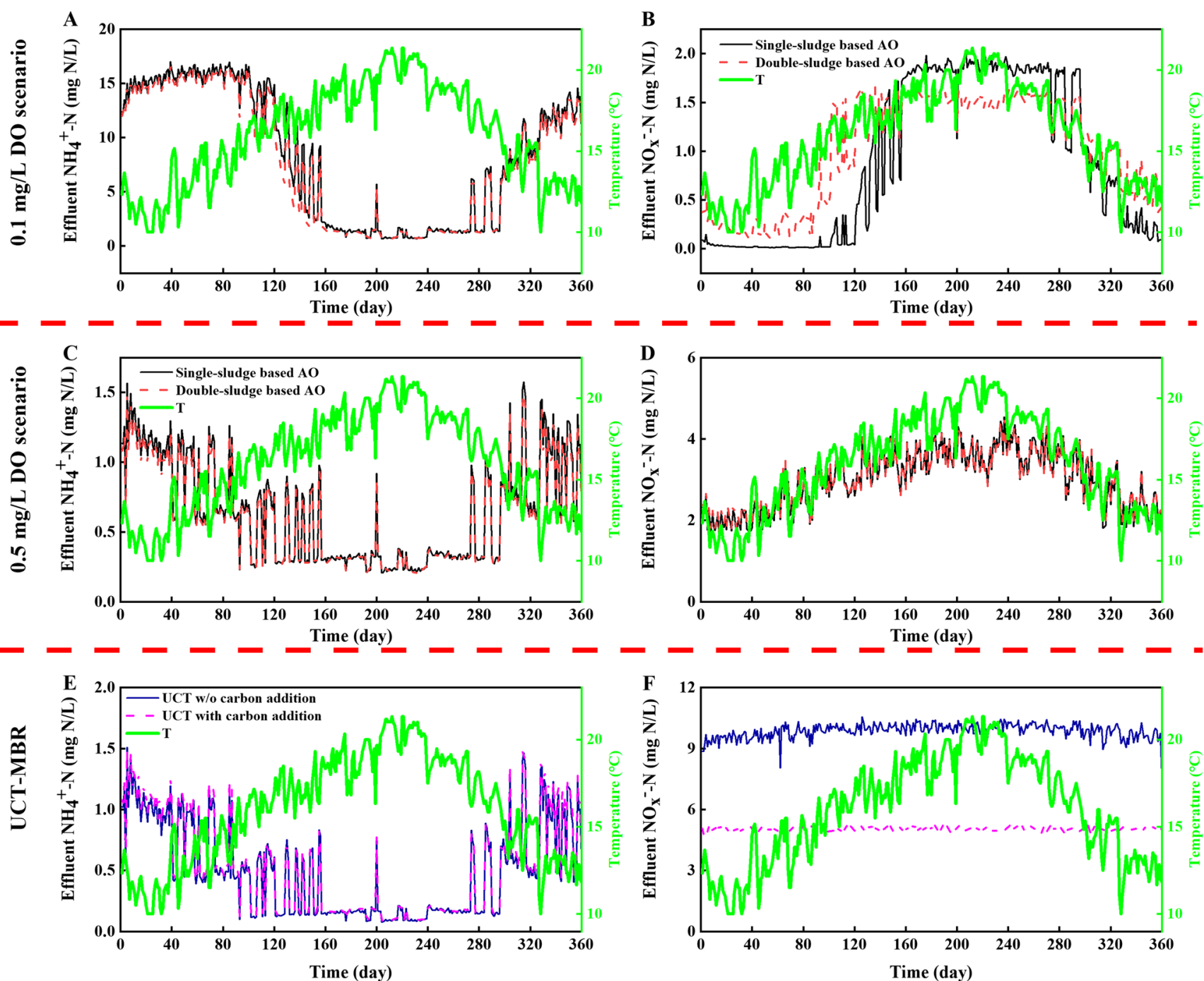

Fig. 9 Effluent $\mathrm{NH}_{4}^{+}-\mathrm{N}$ and $\mathrm{NO}_{3}^{-}-\mathrm{N}$ profiles of the two AO plans under two O-zone DO setting scenarios $(0.1 \mathrm{mg} / \mathrm{L} \mathrm{DO}(\mathbf{A}$ and $\mathbf{B})$ and $0.5 \mathrm{mg} / \mathrm{L} \mathrm{DO}(\mathbf{C}$ and $\mathbf{D})$ ) and the UCT-MBR system with and without external carbon additions ( $\mathbf{E}$ and $\mathbf{F})$
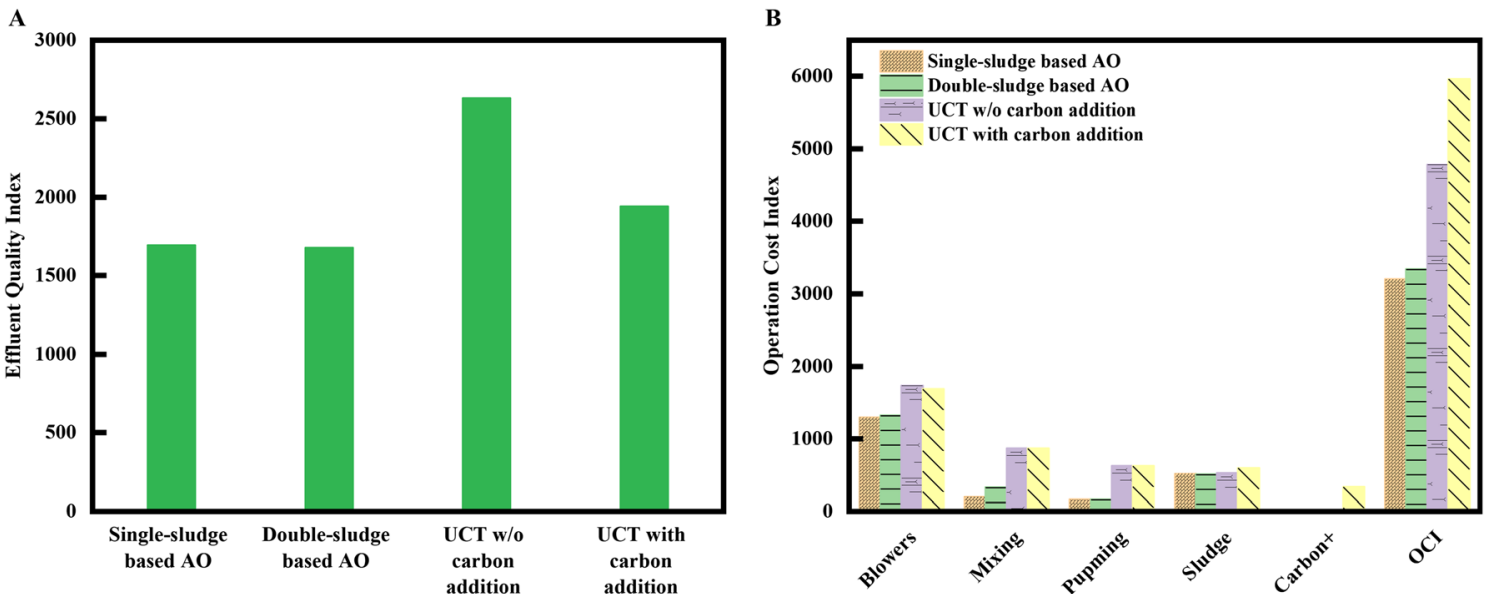

Fig. 10 The comparison of the dynamic simulation performance of the two AO plans under two O-zone DO setting scenarios $(0.1 \mathrm{mg} / \mathrm{L} \mathrm{DO}$ and $0.5 \mathrm{mg} /$ L DO) and the UCT-MBR systems (with and without external carbon additions) 


\section{Engineering implications}

Despite the engineering advantages of anammox, maintaining anammox requires a stable $\mathrm{NO}_{2}^{-}-\mathrm{N}$ supply and a harbor for the slow-growing AMX. In reality, PdN is more controllable than PN, but maintaining PdN might also require proper types of organic carbon, e.g., acetate or glycerol (Cao et al. 2013). In a PdNA study carried by the District of Columbia Water and Sewer Authority (DC Water), it is demonstrated that the organic carbon from raw wastewater should be depleted before $\mathrm{PdN}$ can occur in a controllable manner, and a delicate control of organic carbon addition should also be implemented depending on the $\mathrm{NO}_{3}^{-}-\mathrm{N}$ level in the PdNA unit (Le et al. 2019). In this current model-based study, the depressed AMX activities by each influent feeding under the $0.5 \mathrm{mg} / \mathrm{L}$ DO scenario suggest the need for an even more distributed organic carbon dosage to lower the negative effect from organic loading shocks, e.g., use intermittent carbon source addition to prevent thorough denitrification (Du et al. 2019a), similarly like intermittent aeration is often used to promote PN by preventing full nitrification (Corbalá-Robles et al. 2015).

It is also indicated in this study that the DO change in the Ozone can significantly influence the biological activities in the Azone, which technically presents the A-zone as a flexible "swing" zone that can be further utilized for process optimization. Therefore, this study together with some other recent literature indicates a strong need for implementing advanced process controls to achieve higher wastewater treatment purposes, e.g., cultivating AMX, enhancing the system's resilience to influent fluctuations, etc. (Le et al. 2019; Du et al. 2019a, 2019b; Jia et al. 2020). It becomes evident that the ongoing campaign of evolving from energy-intensive to more energy-efficient or even energyneutral processes cannot be accomplished without the help of more in-depth studies on process control strategies.

Different from high N-containing industrial wastewater that is suitable for mainstream anammox, pushing mainstream anammox for domestic wastewater may face various challenges (Du et al. 2019b; Le et al. 2019). Although the configuration of the A-B process is effective in spatially separating bCOD removal from anammox to ease PNA or PdNA occurrence (Le et al. 2019; Jia et al. 2020), retrofit existing WWTPs will face restrictions that may prevent substantial structural modifications to suit the A-B configuration. Like the developing history of the CAS system that took decades to gradually upgrade from the common secondary treatment to the current era of BNR, the UN SDG campaign will also be a gradual but persistent process depending on the knowledge progress in N-removal mechanisms. Nevertheless, it should be noted that pushing anammox might not be the only available option, and creative aeration strategies can also achieve the same extent of N-removal (Chi et al. 2021; Wang et al. 2021). Therefore, from the engineering perspective, it will be wise to seek a middle ground between conventional
CAS and cutting-edge technologies when it comes to WWTP retrofit. The core is to strategically adjust the spatial-temporal balance between electron donors and electron acceptors over the process train to promote and exploit biological processes that are more energy-efficient and sustainable within the process configuration.

Lastly, it should be highlighted that modeling accuracy is not the ultimate purpose of this model-based study. For example, the sludge concentration in the MBR system is normally higher than that of CAS system and thus promotes diffusional limiting conditions. Thus, the half-saturation constants, not calibrated or verified in this study, are expected to be higher than those of CAS systems. Therefore, the result of this study should not be interpreted in a fully quantitative way since no field verification has been carried yet. However, there are already successful reports to use conservative aeration strategies to promote $\mathrm{N}$-removal in traditional BNR processes (Chi et al. 2021; How et al. 2020; Wang et al. 2021). High-frequency micro-aeration/anoxic has been used to improve the treatment efficiency over low- $\mathrm{C} / \mathrm{N}$ wastewater by directing the limited influent organic carbon to nitrogen and phosphorus removals in an AO system (Chi et al. 2021). Tuning down DO to promote simultaneous nitrification and denitrification has also been proven effective in enhancing nitrogen removals for both AAO and AO systems (Wang et al. 2021; How et al. 2020). Nevertheless, sludge bulking of CAS system could be an issue under low-DO conditions (Henze et al. 2008), and GHG emission under low-DO conditions also needs to be considered in the current days (Ni et al. 2013, 2015). Therefore, the result of this study can be interpreted as a reference for wastewater engineers amidst the current enormous market of WWTP retrofit/upgrade. Although there could be other retrofit plans for this particular project, the ultimate purpose of this study is to concur with the UN SDG that the wastewater industry should and can seek more energy-efficient measures for wastewater treatment. Design/ process engineers should be proactive on this matter to prevent the wrong match between influent characteristics and wastewater treatment processes.

\section{Conclusion}

The potential to enhance the N-removal of an existing UCTMBR system is evaluated in this study. The choice between pushing anammox and enhancing conventional heterotrophic denitrification is assessed through process modeling. The UCT-MBR system is proposed to be converted into an AO configuration and two operation options are compared: one is single-sludge and the other is double-sludge. Conservative aeration is used to promote anoxic processes versus oxic processes, and a multiple influent feeding strategy is used to direct the limited influent carbon source more toward heterotrophic denitrification. 
The simulation result indicates it is feasible to strategically adjust the spatial-temporal balance between electron donors and electron acceptors to enhance N-removal by utilizing the influent organic carbon other than adding external carbon. Tuning down DO can increase the extent of anoxic processes, and multiple influent feeding can direct more bCOD toward heterotrophic denitrification. Although anammox can be noticeably promoted in the double-sludge-based AO plan, the same effluent quality can be achieved by the single-sludge-based $\mathrm{AO}$ plan as well. Furthermore, pushing anammox will weaken the system's resilience to influent fluctuations and demonstrates no economic advantage over the single-sludge-based AO plan. It is indicated that pushing anammox is not the only option for this particular WWTP retrofit task, and a reasonably controlled aeration can also satisfy the N-removal requirement. Overall, this study demonstrates the benefits of process modeling for wastewater process engineers and concurs with the UN SDG that the wastewater industry should and can seek more energy-efficient measures for wastewater treatment.

Supplementary Information The online version contains supplementary material available at https://doi.org/10.1007/s11356-021-14396-2.

Acknowledgements The authors would like to thank EnviroSim Associates Ltd. for their technical support on BioWin. The authors also want to express their sincere thanks to the anonymous reviewers and the handling editor for their precious time and valuable comments on this manuscript.

Author contribution QS carried out simulation and data analysis, and wrote the manuscript draft. FW supplied the data of the WWTP and made inputs to the manuscript. WD offered inputs in Biowin operations and the manuscript draft. JH was responsible for simulation, data treatment, manuscript draft, and coordination among the other authors.

Funding The authors did not receive support from any organization for the submitted work.

Availability of data and materials All data generated or analyzed during this study are included in this published article and its supplementary information files.

\section{Declarations}

Ethics approval and consent to participate Not applicable.

Consent for publication Not applicable.

Competing interests The authors declare no competing interests.

\section{References}

Ali M, Okabe S (2015) Anammox-based technologies for nitrogen removal: advances in process start-up and remaining issues. Chemosphere 141:144-153
American Society of Civil Engineers (ASCE) (2010) Design of municipal wastewater treatment plants.

Cao S, Wang S, Peng Y, Wu C, Du R, Gong L, Ma B (2013) Achieving partial denitrification with sludge fermentation liquid as carbon source: the effect of seeding sludge. Bioresour Technol 149:570 574

Cao S, Peng Y, Du R, Wang S (2016) Feasibility of enhancing the DEnitrifying AMmonium OXidation (DEAMOX) process for nitrogen removal by seeding partial denitrification sludge. Chemosphere 148:403-407

Chi Y, Ren T, Shi X, Jin X, Jin P (2021) Mechanism of nutrient removal enhancement in low carbon/nitrogen wastewater by a novel highfrequency micro-aeration/anoxic (HMOA) mode. Chemosphere 263:128003

Corbalá-Robles L, Picioreanu C, van Loosdrecht MCM, Pérez J (2015) Analysing the effects of the aeration pattern and residual ammonium concentration in a partial nitritation-anammox process. Environ Technol 37(6):694-702

Díez-Montero R, Castrillo M, Casao M, Tejero I (2019) Model-based evaluation of a trickling filter facility upgrade to biological nutrient removal. Sci Total Environ 661:187-195

Dimitrova I, Dabrowska A, Ekström S (2020) Start-up of a full-scale partial nitritation-anammox MBBR without inoculum at Klagshamn WWTP. Water Sci Technol 81(9):2033-2042

Dorofeev AG, Nikolaev YA, Kozlov MN, Kevbrina MV, Agarev AM, Kallistova AY, Pimenov NV (2017) Modeling of anammox process with the biowin software suite. Appl Biochem Microbiol 53(1):88 95

Du R, Cao S, Li B, Zhang H, Li X, Zhang Q, Peng Y (2019a) Stepfeeding organic carbon enhances high-strength nitrate and ammonia removal via DEAMOX process. Chem Eng J 360:501-510

Du R, Peng Y, Ji J, Shi L, Li X (2019b) Partial denitrification providing nitrite: opportunities of extending application for anammox. Environ Int 131:105001

Elawwad A (2018) Optimized biological nitrogen removal of highstrength ammonium wastewater by activated sludge modeling. J Water Reuse Desal 8(3):393-403

Gernaey KV, Jeppsson U, Vanrolleghem PA, Copp JB (2014) Benchmarking of control strategies for wastewater treatment plants. IWA Publishing, UK

Hao X, Li J, van Loosdrecht MCM, Jiang H, Liu R (2019) Energy recovery from wastewater: heat over organics. Water Res 161:74-77

Henze M, van Loosdrecht MCM, Ekama GA, Brdjianovic D (2008) Biological wastewater treatment: principles, modelling and design. IWA Publishing, UK

How SW, Nittami T, Ngoh GC, Curtis TP, Chua ASM (2020) An efficient oxic-anoxic process for treating low $\mathrm{COD} / \mathrm{N}$ tropical wastewater: startup, optimization and nitrifying community structure. Chemosphere 259:127444

Jia M, Solon K, Vandeplassche D, Venugopal H, Volcke EIP (2020) Model-based evaluation of an integrated high-rate activated sludge and mainstream anammox system. Chem Eng J 382:122878

Kartal B, Kuenen JG, van Loosdrecht MCM (2010) Sewage treatment with anammox. Science 328(5979):702-703

Keene NA, Reusser SR, Scarborough MJ, Grooms AL, Seib M, Santo Domingo J, Noguera DR (2017) Pilot plant demonstration of stable and efficient high rate biological nutrient removal with low dissolved oxygen conditions. Water Res 121:72-85

La Rosa G, Bonadonna L, Lucentini L, Kenmoe S, Suffredini E (2020) Coronavirus in water environments: occurrence, persistence and concentration methods-A scoping review. Water Res 179:115899

Laureni M, Falås P, Robin O, Wick A, Weissbrodt DG, Nielsen JL, Ternes TA, Morgenroth E, Joss A (2016) Mainstream partial nitritation and anammox: long-term process stability and effluent quality at low temperatures. Water Res 101:628-639 
Le T, Peng B, Su C, Massoudieh A, Torrents A, Al-Omari A, Murthy S, Wett B, Chandran K, deBarbadillo C, Bott C, Clippeleir HD (2019) Nitrate residual as a key parameter to efficiently control partial denitrification coupling with anammox. Water Environ Res 91(11): $1455-1465$

Li J, Peng Y, Zhang L, Gao R, Lan Y, Liu Q, Zhang Q, Li X, Wang S (2020) Enhanced nitrogen removal assisted by mainstream partialanammox from real sewage in a continuous flow $\mathrm{A}^{2} / \mathrm{O}$ reactor. Chem Eng J 400:125893

Lu L, Guest JS, Peters CA, Zhu X, Rau GH, Ren ZJ (2018) Wastewater treatment for carbon capture and utilization. Nat Sustain 1(12):750 758

Melcer H, Dold PL, Jones RM, Bye CM, Takacs I, Stensel HD, Wilson AW, Sun P, Bury S (2003) Methods for wastewater characterization in activated sludge modelling. IWA Publishing, UK

Ni B, Ye L, Law Y, Byers C, Yuan Z (2013) Mathematical modeling of nitrous oxide $\left(\mathrm{N}_{2} \mathrm{O}\right)$ emissions from full-scale wastewater treatment plants. Environ Sci Technol 47(14):7795-7803

Ni B, Pan Y, van den Akker B, Ye L, Yuan Z (2015) Full-scale modeling explaining large spatial variations of nitrous oxide fluxes in a stepfeed plug-flow wastewater treatment reactor. Environ Sci Technol 49(15):9176-9184

Pan Y, Liu Y, Peng L, Ngo HH, Guo W, Wei W, Wang D, Ni B (2019) Substrate diffusion within biofilms significantly influencing the electron competition during denitrification. Environ Sci Technol 53(1):261-269

Peng Y, Zhu G (2006) Biological nitrogen removal with nitrification and denitrification via nitrite pathway. Appl Microbiol Biotechnol 73(1): $15-26$

Peng Z, Gao D, Xiang T, Wang X (2019) Achieving stable and efficient single-stage deammonification using plug flow reactor. Environ Sci Pollut Res 26:28031-28039

Pérez J, Laureni M, van Loosdrecht MCM, Persson F, Gustavsson DJI (2020) The role of the external mass transfer resistance in nitrite oxidizing bacteria repression in biofilm-based partial nitritation/ anammox reactors. Water Res 186:116348
Seuntjens D, Carvajal Arroyo JM, Van Tendeloo M, Chatzigiannidou I, Molina J, Nop S, Boon N, Vlaeminck SE (2020) Mainstream partial nitritation/anammox with integrated fixed-film activated sludge: combined aeration and floc retention time control strategies limit nitrate production. Bioresour Technol 314:123711

United Nations (2015) Transforming our world: the 2030 agenda for sustainable development. https://sdgs.un.org/2030agenda. Accessed 2021-05-08

US EPA (2020) When a detour becomes a shortcut: going full-scale with partial denitrification/anammox as an alternative strategy for mainstream deammonification and incorporating biological phosphorus removal. https:/cfpub.epa.gov/ncer_abstracts/index.cfm/fuseaction/ display.abstractDetail/abstract/11098/report/0. Accessed 2021-0508

van Loosdrecht MCM, Lopez-Vazquez CM, Meijer SCF, Hooijmans CM, Brdjanovic D (2015) Twenty-five years of ASM1: past, present and future of wastewater treatment modelling. J Hydroinf 17(5): $697-718$

Wang L, Li B, Li Y, Wang J (2021) Enhanced biological nitrogen removal under low dissolved oxygen in an anaerobic-anoxic-oxic system: kinetics, stoichiometry and microbial community. Chemosphere 263:128184

Xie Y, Zhang C, Yuan L, Gao Q, Liang H, Lu N (2020) Fast start-up of $\mathrm{PN} / \mathrm{A}$ process in a single-stage packed bed and mechanism of nitrogen removal. Environ Sci Pollut Res 27:40483-40494

Zhang W, Peng Y, Zhang L, Li X, Zhang Q (2020) Simultaneous partial nitritation and denitritation coupled with polished anammox for advanced nitrogen removal from low $\mathrm{C} / \mathrm{N}$ domestic wastewater at low dissolved oxygen conditions. Bioresour Technol 305:123045

Zhu G, Wang S, Bin M, Wang X, Zhou J, Zhao S, Liu R (2018) Anammox granular sludge in low-ammonium sewage treatment: not bigger size driving better performance. Water Res 142:147-158

Publisher's note Springer Nature remains neutral with regard to jurisdictional claims in published maps and institutional affiliations. 